Linköping studies in science and technology

Dissertation No. 1796

\title{
Chicken domestication: \\ Effects of tameness on brain gene expression and DNA methylation
}

Johan Bélteky

IFM Biology

Department of Physics, Chemistry and Biology

Linköping University, SE-581 83, Linköping, Sweden

Linköping 2015 
Chicken domestication:

Effects of tameness on brain gene expression and DNA methylation

Linköping studies in science and technology

Dissertation No. 1796

ISBN: 978-91-7685-669-7

ISSN: 0345-7524

Front cover: Red Junglefowl

Photo: Per Jensen

Copyright Johan Bélteky

Printed by LiU-Tryck, Linköping, Sweden, 2016 




\section{Abstract}

Domestication greatly increases phenotypic variation in a short time span, with selection for a single phenotype and a plethora of associated phenotypic changes as an outcome of the process. The domestication process influences the underlying genomic architecture of a species, and the success and speed of the process is likely influenced by it. The main aims of my thesis was to study how domestication affects the brain of chickens: specifically changes in morphology, gene expression, and DNA methylation. Differences in gene expression and DNA methylation between White Leghorn and Red Junglefowl chickens were mapped, and inheritance of these patterns were quantified, indicating a faithful transmission of breed-specific epigenetic markers. Selection on the behavioral trait fearfulness, generated high and low fearful lines of Red Junglefowl. Both the parental population and the fifth selected generation were used for the analyses in this thesis. One experiment studied morphological changes in the brain and other vital organs, and found that relative total brain size increased in high fearful birds, as a consequence of an increase in cerebral hemisphere size in high fearful birds and not in low fearful birds. Also, the relative heart, liver, spleen and testis size increased in high fearful birds, indicating correlated morphological changes with selection for fearfulness. Two additional experiments examined differential gene expression in the hypothalamus and the anterior cerebral hemisphere. The hypothalamus differed in expression of genes with reproductive and immunological functions, whilst the cerebral hemisphere differed in expression of genes related to social behaviors and neurological functions especially those upregulated in low fearful birds. These results indicate the occurrence of tissue- and species-specific changes in gene expression as overlap with other domestication events were nearly nonexistent. A fourth experiment sought to associate the change in fear levels and gene expression differences with DNA methylation. Chromosomal regions with differential DNA methylation between high and low fearful birds were identified, and genes in these regions had annotated functions relevant to phenotypic differences between the selection lines. This thesis is the first to study the genetic alterations of domestication using the wild ancestor of an already domesticated species to repeat the domestication process selecting against fear of humans. The findings corroborate results from previous comparisons of wild and domestic animals, and further support the theory that rigorous selection for a behavioral trait can cause a cascade of genetic and epigenetic changes facilitating the domestication of a population. 


\section{Populärvetenskaplig sammanfattning}

Domesticering, när en population djur anpassas till ett liv i fångenskap och nära kontakt med människor, är en process som under kort tid ger upphov till stora förändringar hos djuret under selektion, såsom skillnader i beteende, fysiologi, storlek, reproduktion och färg i päls och fjäderdräkt. Vi har här haft ett särskilt fokus på det röda djungelhönset, som är förfadern till alla våra domesticerade höns. Med sitt ursprung i Syd- och Sydostasien, där den även återfinns idag, började den röda djungelhönan domesticeras för drygt 8000 år sedan för att ge upphov till ett av vårt mest använda produktionsdjur för både kött och ägg. Att djungelhöns än idag finns kvar är till stor fördel då de kan användas för jämförelse med tamhöns och kvantifiera skillnader som uppkommit under domesticeringen. De grundläggande förutsättningarna för hur höns domesticerades är inte klarlagda, men utifrån de stora skillnaderna mellan röda djungelhöns och tamhöns måste de i ett tidigt skede ha selekterats för minskad rädsla för människor och den nya främmande miljön för att frodas och kunna reproducera sig.

Med utgångspunkt från röda djungelhöns har vi under fem generation i två separata populationer selekterat för ökad eller minskad rädsla för människor, med målet att generera en rädd population höns och en orädd population som ska representera domesticerade röda djungelhöns. Selektionen har gett upphov till signifikanta skillnader i nivå av rädsla mellan de två populationerna, och har dessutom bidragit till andra skillnader så som att orädda höns är fysiskt större, lägger större ägg, är mer dominanta och aggressiva vid konkurrens om mat, och har mer välvårdad fjäderdräkt.

I den här avhandlingen har först genetiska och epigenetiska skillnader mellan röda djungelhöns och White Leghorn, en hönsras framavlad för äggproduktion, studerats. Vi fann signifikant olika signaturer i mängden genuttryck för ett stort antal gener mellan de två raserna, och även skillnader i mängden DNA-metyleringar, en markör som kan reglera genuttryck. Teorin är att domesticering har gett upphov till många genetiska skillnader kopplade till de skillnader i bland annat beteende och fysiologi som noterats mellan raserna. Epigenetiska markörer kan ha påverkats av domesticeringsprocessen, men kan likväl ha varit ett hjälpmedel som drivit på domesticeringen och den mängd skillnader som uppstått ur ett evolutionärt sett kort tidsspann.

I jämförelsen mellan rädda och orädda djungelhöns har vi i femte generationen sett skillnader i både total hjärnvikt och i specifika hjärndelar, till exempel är storhjärnan större hos rädda höns än orädda, en förändring som iakttagits hos många domesticerade djur där storhjärnan har minskat i volym. I både hypotalamus och främre storhjärnan fann vi signifikanta skillnader i genuttryck mellan rädda och orädda höns, med förändringar som tyder på en koppling till reproduktion och immunologi i hypotalamus, och socialt beteende och neurologiska faktorer i främre storhjärnan. Majoriteten skillnader i genuttryck mellan rädda och orädda höns 
överlappar inte med jämförelsen mellan röda djungelhöns och White Leghorn, och kan tyda på att selektionstrycket initialt påverkar gener som inte är aktiva i senare skeden av domesticeringsprocessen. Antalet DNA-metyleringar var inte större i orädda höns än rädda, trots tidigare sådana observationer mellan domesticerade och vilda höns, men de specifika regioner som skiljer rädda och orädda höns åt kan vara viktiga bidragande faktorer till de snabba förändringarna i selektionslinjerna.

Tillsammans visar resultaten att selektion av höns baserat på rädsla för människor under några få generationer snabbt orsakar förändringar förenliga med tidigare studier av domesticeringsprocessen, och att förändringar av rädsla är kopplade till genuttryck och epigenetiska markörer. 



\section{List of publications}

\section{Paper I}

Nätt, D, Rubin, C. J, Wright, D, Johnsson, M, Bélteky, J, Andersson, L, Jensen, P. (2012). Heritable genome-wide variation of gene expression and promoter methylation between wild and domesticated chickens. BMC Genomics 13 (59).

\section{Paper II}

Agnvall B, Bélteky J, Jensen P. "Brain size is reduced by selection for tameness in Red Junglefowl - correlated effects in vital organs". Submitted manuscript.

\section{Paper III}

Bélteky J, Agnvall B, Johnsson M, Wright D, Jensen P. (2016) “Domestication and tameness: brain gene expression in red junglefowl selected for less fear of humans suggests effects on reproduction and immunology". Royal Society Open Science 3: 160033 .

\section{Paper IV}

Bélteky J, Agnvall B, Jensen P. "Gene expression of behaviorally relevant genes in the cerebral hemisphere changes after selection for tameness in Red Junglefowl”. Submitted manuscript.

\section{Paper V}

Bélteky J, Agnvall B, Bektic L, Jensen P. "Epigenetics and early domestication: Hypothalamic DNA-methylation differences in Red Junglefowl divergently selected for reduced fear of humans". Manuscript. 



\section{Table of contents}

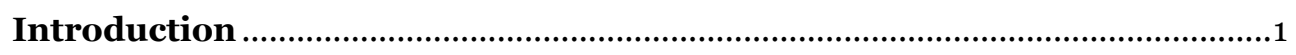

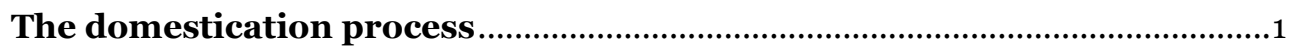

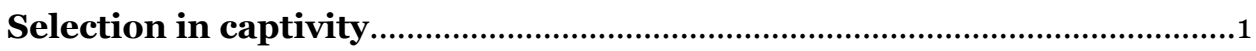

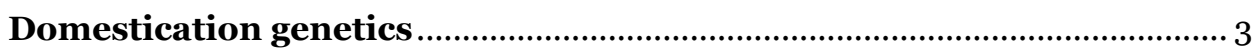

Chicken domestication .............................................................................. 4

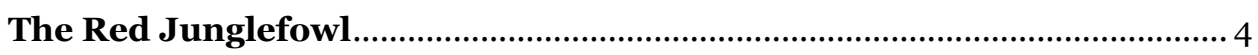

From wild to domestic chicken .................................................................. 5

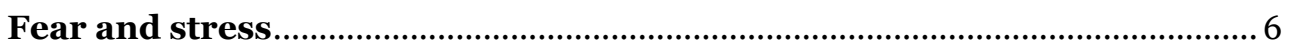

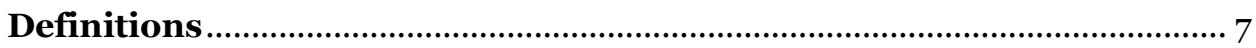

The stress response

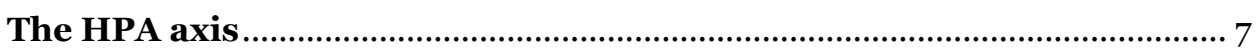

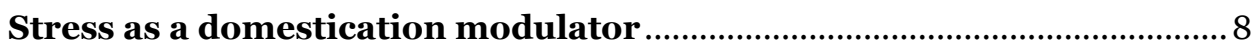

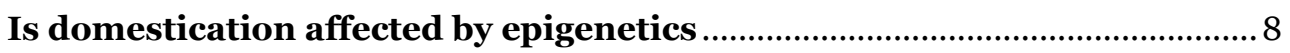

DNA methylation ……...............................................................................

Examples of DNA methylation regulating expression ................................ 10

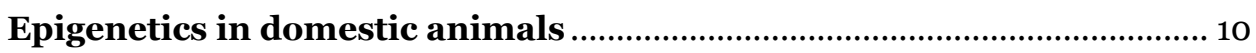

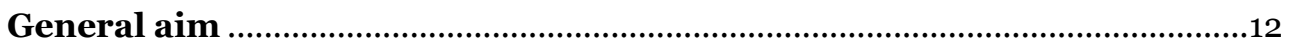

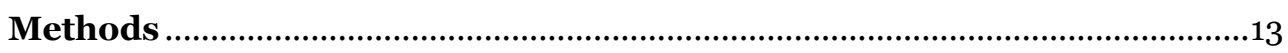

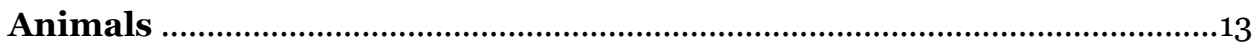

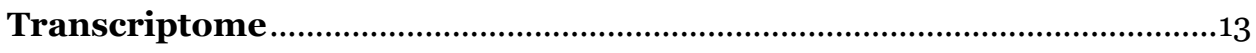

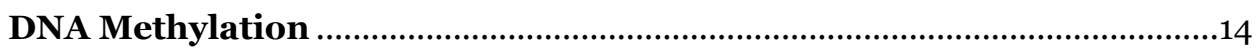

Summary of papers ………………………………....................................

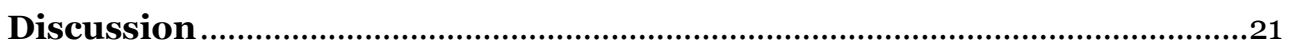

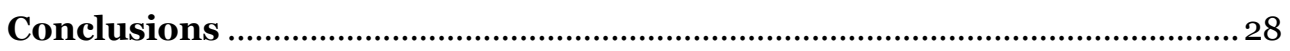

Acknowledgements...................................................................................... 30

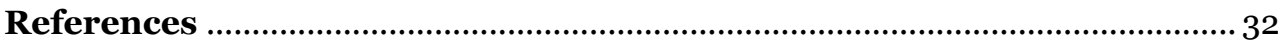





\section{Introduction}

\section{The domestication process}

Domestication is the process by which animals are habituated to their captive environment and the presence of humans throughout generations of artificial selection. More specifically, the most cited and significant definition by Edward Price reads as follows [1];

[Domestication is] that process by which a population of animals becomes adapted to man and to the captive environment by some combination of genetic changes occurring over generations and environmentally induced developmental events occurring during each generation'.

Parts of this definition are debated, as environmental experiences per se cannot have a meaningful impact on the domestication of a species unless there are underlying genetic components for the transmission of such experiences [2], topics I will return to later in this thesis. Among the oldest domesticated species are the dog and livestock animals, specifically pig, sheep, cattle and chickens, some domesticated over 10000 years ago [3-6]. The domestication timespan is relatively short from an evolutionary point of view, yet in no wild species do we see such variation and novelty of traits as in the domesticates [7]. The domestic phenotype, or domestic syndrome, is the collective name for the phenotypic traits altered during the adaptation of domestic animals. Traits affected by domestication can be largely grouped in three categories: morphological, physiological, and behavioural. Morphological changes include general reduction of brain size, depigmentation of fur, skin and feathers, and reduction of bone size $[8,9]$. Physiological changes include an earlier onset of sexual maturity and an increased frequency of oestrus cycles, neotony, and an altered temporal sensitive period of socialization [8-12]. Behavioural changes include reduced fear, aggressiveness and antipredator responses, increased sociability, and altered vocalization patterns [1, 13-16]. As summarized by Sánchez-Villagra et al [17], the dog is the clearest example of a domestic species with the highest account of phenotypic changes.

\section{Selection in captivity}

The interaction between genotype and the environment determines the phenotype of an organism, but how this interaction occurs is not clear [18]. Adaptation to particular environmental conditions shape the behaviour of a wild animal. The captive environment might be perceived as stressful, with foreign odors, unnatural sounds, restricted space, different light conditions and uncharacteristic social groups [19]. The most distinct component of a captive environment is the close proximity to humans, a factor that may induce behavioral changes not found in wild-reared animals. However, 
breeding animals without a selection goal may not be enough to change behavior or hormonal responses [20].

Domestication generally selects for behavioural traits such as tameness, low aggression, and the ability to cope with certain stressors such as crowding [21]. While studying Norway rats, Richter [12] remarked on the selection during domestication:

'By selection we mean here not the natural selection of wild rats in their natural habitat where the wildest, fiercest, and strongest -the fittest for the environment- survive, but selection in the artificial environment of the laboratory, where the fittest for this type of environment survive -those that are most tame, gentle and fertile'.

Expanding on these ideas, Russian geneticist Dimitri Belyaev initiated a selection experiment on foxes in Novosibirisk about 55 years ago. Convinced that selection for tameness mimicked the selection pressure that domesticated wolves into dogs, Belyaev suggested that selection against fear of humans could interrupt endocrine pathways, which would lead to cascading effects in many systems [22]. Dramatic changes occurred in only a few generations due to this 'destabilizing selection'. Behaviorally, foxes acted more like dogs, seeking attention from humans, wagging their tail and also licking and displaying friendly behaviour toward the human experimenters. The frequency of these behavioral traits in the population changed rapidly, with only $1.8 \%$ displaying the human contact seeking behavior in the sixth selected generation, $17.9 \%$ in the tenth generation and $49 \%$ by generation thirty [23]. Further, the plasma corticosteroid levels decreased and significant physiological changes occurred in about ten generations after selection began. The coat color changed, tails curled and ears became floppy, legs and tails started to shorten (chondystrophy) and their noses became shorter along with a proportional reduction of their skulls (brachycephaly). Changes in tails, ears and coat colors also occur simultaneously in farm-bred foxes despite the lack of selection for tameness. The frequency of these changes were, however, tenfold higher in the domesticated foxes after only eight to ten generations of selection. Changes also occurred related to reproduction. Sexual maturity onset was one month earlier and litter sizes increased by approximately one pup, with up to two litters per year instead of one as the mating seasons were prolonged. The selection experiment has since been repeated in mink and rats with similar outcomes [24, 25]. All of these traits resemble those already seen in historically domesticated animals, suggesting that selection for a behavioral trait such as tameness can pleiotropically produce many of the traits associated with the domestic phenotype. Later paragraphs will describe what effects stress in captivity can have on genetic and phenotypic changes, and the role of epigenetics as a pathway for conveying information from the environment through the genome below. 


\section{Domestication genetics}

Domestication is not an immediate process, but rather it is continuous and gradual, and involves genetic changes $[9,26]$. The most influential of the genetic changes are selection, inbreeding, and genetic drift. Price and King have identified three major selective mechanisms that affect gene frequencies in captive populations; artificial selection, natural selection in captivity, and relaxed natural selection [12, 27]. The first mechanism, artificial selection (coined by Darwin [7]), is the selection of traits desired by humans. In past domestication events, the highly fearful animals or those displaying aggression against humans were likely removed from the breeding pool, whilst animals that were easy to handle were preferred for breeding purposes. Secondly, natural selection in captivity act early in the domestication process to eliminate individuals that cannot produce offspring in captivity. Finally, relaxed natural selection occurs when the conditions in captivity enable or favor behavioural traits which in wild conditions would have been selected against. For example, captive conditions usually do not include parasites or predators and animals have ample access to food, thus traits as vocalizations have a lower threshold in domestic animals. In contrast to selection, the other influential genetic changes, inbreeding and drift, cause random changes in regards to allele frequencies. Founder effects and bottlenecks occur early in domestication and later breed isolation affects allelic diversity, despite backcrossing events with wild genotypes or other species [28-30]. Commercial chicken breeds, for instance, have lost up to $50 \%$ of the allelic diversity compared to non-commercial breeds [31]. With the aid of domestic animals as models, many traits subjected to selection and regulated by a single locus have been mapped, such as $M C 1 R$ regulating coat color in a number of domesticates (for a full review see [32]). Most traits however have a complex inheritance pattern, regulated by many different genes and environmental elements, and are difficult to disentangle due to factors such as clustered linkage and pleiotropic effects.

Uniform theories for the underlying genomic cause for the domestic phenotype have been suggested. Besides Belyaev's destabilizing selection, which will be discussed later in the context of stress, a recent theory suggests a link to changes in neural crest cells (NCCs) [33]. NCCs are vertebrate-specific stem cells that emerge in the neural tube early in embryogenesis and migrate to form cellular precursors influence developmental patterns. Tissues derived from NCCs include many of the areas affected by the domestic phenotype: melanoblasts, the adrenal medulla, the sympathetic ganglia, and large parts of the skull. Selecting for tameness should produce embryonic neural crest cell developmental deficits which could cause many of the phenotypic changes associated with domestication. One specific example is the piebald pattern of depigmentation in domestic silver foxes; a delayed migration of melanocytes from the neural crest to the epidermidis in the embryo may lead to the death of the late melanoblasts [9]. The delayed migration is influenced by the Star $(S)$ gene, and possibly the agouti protein [34], and I will come back to Star later on in the text as it is influenced by both endocrine and epigenetic factors. 
Both of the abovementioned theories assume pleiotropic effects, with a few causal changes affecting many traits. As expected, allelic diversity between ancestral and domesticated animals has had a significant effect on transcriptomic changes, and production related tissues such as the liver, muscle and adipose tissue [35-37]. Also tissues affecting behaviour such as the adrenals and the brain have been of great interest [38-42]. Of particular importance is a study by Albert et al [38] in which four domestic mammals were compared in order to find convergent transcriptional genes or pathways to domestication. Overall, few genes differed in expression when comparing wild and domestic dogs, pigs and rabbits, whereas the differential expression between guinea pig and the cavy was much greater. Comparisons between all four sets of differentially expressed genes revealed no overlapping genes for all the domestication events. Additionally, the comparison between rats selected for tameness or aggression against humans revealed a low number of differentially expressed genes, with only one overlapping when compared to the four other domesticated species. Two of the most differentially expressed genes in the rats, $D L L 3$ and $D H D H$, overlapped with a previously identified quantitative trait loci (QTL) for tameness and aggression in the same rat population, providing candidate genes affecting tameness in domesticated rats [43]. Similarly, silver foxes has shown differences in brain gene expression of varying degree as a result of selection for tameness [44, 45]. Effects caused by the domestication process that persist in a population across generations must have a mode of transmission, and the domestic phenotype encompasses so many changes in such a short time that mutation rates alone cannot explain the appearance of all of the variation. For this purpose, domesticated animals are impeccable models in exploring mechanisms that can aid in shaping selection, such as epigenetics.

\section{Chicken domestication}

\section{The Red Junglefowl}

The chicken, Gallus gallus domesticus, is the most common and abundant production animal today. With nearly 70 billion chickens worldwide used for both egg and meat production, it is one of the most important domesticated animals [46]. The domestic chicken originates from the wild Red Junglefowl (RJF), Gallus gallus, a bird of the Galliformes order native to South- and Southeast Asia. The Red Junglefowl, still found today in parts of Asia [47] and the Hawaiian islands, was the subject of domestication approximately five to eight thousand years ago [48, 49]. Along with the Red Junglefowl, three other birds of the genus Gallus are found in India and Southeast Asia: Sri Lankan Junglefowl (Gallus lafayettii), Grey Junglefowl (Gallus sonneratii) and the Green Junglefowl (Gallus varius). 


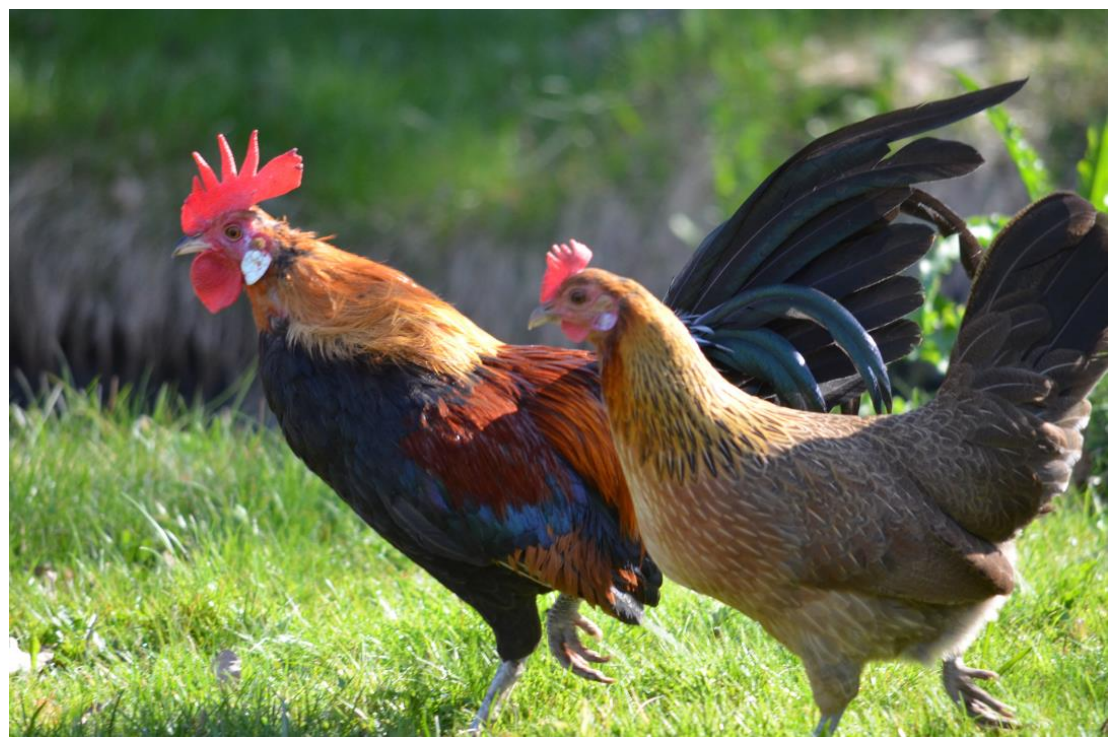

Figure 1. Male (left) and female (right) Red Junglefowl on the run (Photo: Per Jensen)

The Red Junglefowl shows strong sexual dimorphism between the male and female (Fig 1), features that have been lost in domestic production animals with the exception of some sexually selected traits like combs. In the wild, they form groups comprising one dominant male and several females, with subdominant males at the fringe of the group. During the breeding season, which typically falls between March and May, males are often seen alone whilst females rarely venture alone. The Red Junglefowl spends large parts of the active daily period on foraging behaviors, and synchronizes preening and bathing behaviors $[50,51]$. They feed on various seeds, fruits, insects, spiders and snails depending on the season, and competition for food is determined by a peck order, with dominant individuals chasing away subordinate ones by lunging at them. Due to predation risk, Red Junglefowl are highly vigilant and spend the night perched on branches $[51,52]$. If disturbed or followed, they go through great lengths relocating to new grounds and the frequency of crowing diminishes. Depending on the threat, Red Junglefowl will respond by staying immobile until the perceived danger has passed, or emit alarm calls which prevents other vocalizations. Overall, the Red Junglefowl has been described as a highly fearful bird in the wild.

\section{From wild to domestic chicken}

As with many other domesticates, the location and exact time for domestication is still debated [53, 54]. Mitochondrial sequences suggest several different domestication events for Red Junglefowl $[55,56]$. Pinpointing the specific events is made difficult by early mixing between the wild and domestic breeds. The Red Junglefowl has also been crossed with other species of Junglefowl. One such specific event concerns leg color, a trait that comes from an introgression with the Grey Junglefowl [29]. The Red 
Junglefowl has grey legs, and the fact that many domestic breeds today have yellow legs indicate an esthetic selection for the trait.

Historical and archeological records suggest that early domestication was mainly for cultural reasons such as religion, art, and entertainment, and only later for production aspects $[57,58]$. Initially, the captive chicken is thought to have been used for cock fighting [46]. Data from medieval sources suggest that the selection for production traits in chickens did not start until the $16^{\text {th }}$ or $17^{\text {th }}$ century [59], with selection for variation in TSHR, thyroid-stimulating hormone receptor, a mutation affecting seasonal reproduction $[60,61]$. Up until the beginning of the $20^{\text {th }}$ century, the chicken was a dual purpose animal with the same breed used for both meat and egg production. This changed when selection pressure increased separately for the production traits of today's specialized market- breeds for increased egg laying, such as the White Leghorn which lay 300 eggs per year, and breeds for meat production, such as the broiler which can weigh more than four times that of the wild Junglefowl [62].

With both the domestic chicken and its wild ancestor readily available, effort has been put into characterizing the behavioral differences between them as a result of domestication. The White Leghorn spends less time exploring and more time foraging than the Red Junglefowl [63-65]. Whilst social organization is maintained in the domesticated chicken, with pecking orders and a dominance structure, the White Leghorn shows less intense social behavior and a reduction in the frequency of social interactions, with more aggressive behavior in certain group compositions [66]. A mutation present in most domestic production fowls is the white plumage, caused by a mutation in gene PMEL17, also known as dominant white $[67,68]$. Variation in PMEL17 and plumage color has been correlated with behavioral differences, suggesting that a white plumage protect individuals from feather pecking $[69,70]$. Egg layers show altered and less extreme antipredatory behavior, and fear related behaviors in the chicken have been reduced, maybe as the co-existence with humans has relaxed the natural selection pressure of predation $[71,72]$. Transmission of behavioral differences over generations has been shown to have underlying genetic components [73, 74], as do differences in fear within populations [75].

\section{Fear and stress}

Fear and the stress response crucially influence the domestication process, both as aspects of selection in captivity, and in Belyaev's destabilizing selection theory. The stressful environment can have an immediate effect on animals in captivity, as well as consequences spanning several generations. After the summary of the stress response, some examples will be presented on variation in fear and stress in domesticated populations and their consequences. 


\section{Definitions}

Fear can be seen as negative emotion generated by a specific stimulus (such as darkness, predators, or novelty), by the physical characteristics of a stimulus, (movement, suddenness, or proximity), and can also be generated by interactions with conspecifics (reviewed in [76]). The main function of the stress responses is to alert the individual and prepare it to act in an appropriate way. The complete stress response is a complex phenomenon that integrates the nervous system, neuroendocrine signaling and behavioural responses in order to react appropriately. The definition of stress varies with the author, and much focus has been on the disruption of homeostasis, thereby including many different responses, not all being dangers to the organism. However, Koolhas et al state that the use of the term stress should be limited to instances where an individual perceives events as negative and the adaptive capacity is exceeded by the stress response [77]. Events that are perceived as positive but still invoke the physiological responses should be considered normal physiological mechanisms and not stress.

\section{The stress response}

The stress response to a potential danger is a series of reactions that can be broken down into four main responses: the autonomic nervous system, the immune system, the endocrine system, and behavioral outcomes (for a full review see [78]). Firstly, the sympathetic nervous system activates as a response to a stressor with a release of catecholamines [79]. This hormonal response increases the heart rate and blood pressure and allocates energy resources to the muscles, in preparation for fight or flight. At this point, the organism can choose to try to remove itself from the threat, a behavioral response which then leads to an abolition of any further response [8o]. The behavioral response to acute stress characteristically manifests as alterations in foraging behavior and increased vigilance [65]. This is followed by a second wave of hormonal activity, this time ending with the release of glucocorticoids, such as corticosterone in birds.

Responses can be immediate, with the sympathetic nervous system being activated by acute stressors and only staying active for a brief period of time, or prolonged with long-lasting effects. Increased levels of glucocorticoids for longer durations of time have adverse effects on the organism, among them impaired immune function [81, 82], decreased reproduction [83], impaired growth [84], changed cognitive functions [73], and behavioural abnormalities [85].

\section{The HPA axis}

The hypothalamic-pituitary-adrenal axis (HPA-axis) is responsible for the neuroendocrine response upon exposure to stress, and this pathway ultimately ends with the release of glucocorticoids [8o]. The hypothalamus is the first tissue to activate 
upon the perceived signs of stress. This starts a cascade in which corticotrophin releasing hormone (CRH) and vasopressin are synthesized in the paraventricular nucleus, which then regulate the synthesis and release of adrenocorticotrophic hormone (ACTH) from the anterior pituitary. The role of ACTH is to stimulate uptake and conversion of cholesterol to corticosterone. ACTH also stimulates the adrenal cortex to produce and release glucocorticoids, the final step in the cascade. Glucocorticoids then act as negative feedback on the HPA-axis by inhibiting the production of $\mathrm{CRH}$ and also repressing the cleavage of proopiomelanocortin into ACTH.

\section{Stress as a domestication modulator}

In a population experiencing stress, selection for traits might act more strongly than in an unaffected population [86]. The characteristic effects of stress are all seen in wild animals put in captivity, and need to be extinguished in order for a captive population to be able to thrive. As different genetic variations become involved, selection might act more efficiently and the disturbance of homeostasis may well increase mutagenesis (see Belyaev and Borodin [87] for examples). Selection for stress resistance, such as the domestication process, acts rapidly to alter the hormonal balance in order to ensure survival, and as a consequence, phenotypic variation changes based on the underlying genetic variation. In Belyaev's foxes selected for tameness, males showed lowered plasma cortisol and ACTH levels [88], and similar selection experiments have shown a decrease in plasma corticosterone and brain serotonin in rats [25], whilst fearful minks show higher plasma cortisol after handling but no alteration in cortisol secretion [24]. Related is the atrophy of adrenal glands as a result of selection for tameness [12, 25, 89], with QTLs overlapping for both tameness and adrenal gland weight in rats [43]. Glucocorticoids affect melanoblast migration and coat color in rat, similar to observations in silver foxes [90], and domestic silver foxes and rats have lower levels of glucocorticoids compared to their aggressive counterparts during gestation, further indicating a role for stress hormones involvement in the domestic phenotype. Stress responses and transgenerational inheritance have also changed in the chicken, with domestic breeds being more susceptible in certain aspects [73]. Altered behavioral phenotypes and gene expression patterns are inherited by the offspring from their parents [91, 92], implying the involvement of mechanisms that can aid in the transmission of environmental stimuli across generations, and suggesting a role for epigenetic mechanisms.

\section{Is domestication affected by epigenetics}

Part of the definition of domestication focuses on the importance and ability for an animal to adapt to its new environment. As the animal is in captivity, it will be exposed to that environment generation after generation, and the process might be sped up if environmental information could be genetically passed on across generations. 
Transmission of information in such a manner could be detectable through molecular genetic lab work and could also be a partial explanation for the rapid increase in phenotypic variation within domestic animals.

Coined by Waddington [93] in the 1940s, the term epigenetics as "the branch of biology that studies the causal interactions between genes and their products which bring the phenotype into being" [94] broke into mainstream research only in the late $2 \mathrm{O}^{\text {th }}$ century. The idea of a layer of genomic regulation "above" the genetic code was on the fringe of science until methods for the analysis of epigenetic mechanisms had developed to sufficiently study them. Epigenetics has since been defined by Bird as 'the structural adaptation of chromosomal regions so as to register, signal or perpetuate altered activity states' [95]. This definition is broad enough to encompass the major regulatory mechanisms of DNA methylation and histone modifications, but leaves out more recent findings regarding long noncoding RNA and their interactions. Among the different definitions and uses [96, 97], Bird's will be used in this thesis. Regarding the dichotomy in the field as a result of varying definitions [98], this thesis will consider epigenetics as a phenomenon in both the genetic context as well as for environmentally mediated phenotypes.

\section{DNA methylation}

DNA methylation is one of the most extensively studied epigenetic modifications. Methylation occurs on position five in cytosine (5-methylcytosine), and is generally considered a stable modification as it does not induce DNA repair mechanisms or consequent changes of DNA nucleotides upon methylation. Adding to the complexity is that cytosine methylation mostly occurs when it is followed by a guanine on the DNA strand in animals, dinucleotides referred to as CpGs, cytosine-phosphate-guanine. $\mathrm{CpG}$ dinucleotides are scarce in the genome, with the exception of sites referred to as CpG islands $[99,100]$. Located upstream of genes, and co-localizing with promoters, these regions allow for transcriptional regulation of tissue specific genes via hyper- or hypomethylation at these sites $[101,102]$. The role of DNA methylations in the genome is two-fold. Methylation markers can inhibit or activate gene expression depending on the region where they are located, making them a versatile marker for regulatory control [103-106]. As for the transmission of methylated cytosine in cell division, proteins specializing in methylation maintenance after replication ensure faithful inheritance of epigenetic markers [107]. Epigenetic modifications can also survive the reprogramming events during fertilization and embryonic development, meaning that the DNA-methylome may be inherited over generations, leading to heritable epigenetic effects with markers that can stay for several generations [108, 109]. Adding another layer of complexity to DNA methylation and its effect on genome is the potential mutagenic effects, a potential driver for evolution [110, 111]. 


\section{Examples of DNA methylation regulating expression}

A classic mammalian example of DNA methylation regulating expression is found in the viable yellow mutation, $A^{v y}$, affecting the coat color gene agouti in mice. Viable yellow is caused by the insertion of an intra-cisternal A particle (IAP) containing a cryptic promoter just upstream of the agouti gene [112]. Normally, agouti encode a signaling protein which changes the synthesis of eumelanin to pheomelanin, causing a yellow sub-apical band to appear in the otherwise black hair, giving the mice its wildtype color. The IAP insertion disrupts this process, unless silenced epigenetically [113]. The epigenetic patterns are unstable, in the sense that they give rise to phenomena such as variegation between cells and variable expression between individuals in a nonmendelian pattern, seen as different phenotypes ranging from agouti to pseudo-agouti [114]. Additionally, factors such as nutrition can affect the methylation in the IAP insertion, effectively altering expression patterns and the phenotype [115].

DNA methylations can affect behavior, and behaviors can in turn change methylation patterns. The epigenetic pattern of the glucocorticoid receptor (GR) in rats are influenced by the type of maternal care the offspring receives [116]. This treatment will alter the physiological response to stress through a causal relation between histone modifications, DNA methylation, glucocorticoid receptor (GR) expression, and binding of NGF-inducible protein A (NGIF-A) to the GR promoter. Similarly, serotonin transporter SLC6A4 promoter methylation in humans affects gene expression and correlates with behavioral phenotypes [117]. Dysfunction of SLC6A4 has been implicated in behavioral disorders [118].

\section{Epigenetics in domestic animals}

Epigenetic patterns, influenced by the environment and heritable, could provide a rapid way of altering transcriptional regulation in domestic animals and account for non-Mendelian inheritance patterns (discussed in [119-122]. Recent understanding and techniques have improved the field greatly since Lickliter and Ness [123] stated:

'In similar fashion, we propose that students of domestication ought also to turn their attention to the empirical study of the developmental basis of phenotypic change associated with captivity and domestication. The process of domestication is currently undercharacterized in both genetic and environmental representations, with epigenetic development above the level of the genes virtually ignored in contemporary theory'.

A review of environmental epigenetic effects in domestic farm animals reveal many instances of phenotypic changes correlated with epigenetic change [124], yet the transgenerational aspects are still lacking. 
In Belyaev's farm-fox experiment, spontaneous mutations cannot account for the high frequencies $\left(10^{-1}-10^{-4}\right.$ per generation) of variations that appeared [125]. For example, the coat color changes in foxes resemble those seen in dogs, and point to similar genes being involved in the regulation of behaviour and pigmentation. The agouti loci, discussed earlier, is an example of a loci affecting color as well as hormonal interactions $[126,127]$. The star gene, $S$, responsible for coat color changes in several domestic species, may be epigenetically silenced as heterozygous crosses in foxes has shown irregular segregation in offspring [23]. Furthermore, vixens exhibiting tame behavior and which are heterozygous for the star mutation produce more male than female offspring [128]. 


\section{General aim}

The overall aim of the thesis was to explore the hypothesis that domestication can be achieved through selection for a single trait, the reduction of fear of humans in a population, i.e. tameness.

The aim of Paper I was to study the correlation between the DNA methylome and gene expression in domesticated Wild Leghorns compared to the ancestral Red Junglefowl. This study also investigated transgenerational inheritance of expression and DNA methylation patterns in an attempt to map differences within and between breeds.

The general aim of Papers II to V was to work with the two selection lines (high and low fearful Red Junglefowl) to study the effects of bidirectional selection for tameness. Large phenotypic differences have been reported between the lines. Based on the results Paper I the aim was to study gene expression and DNA methylation patterns in the brain (Papers III to V), as well its morphology (Paper II), to determine the influence of selection for tameness on these aspects. 


\section{Methods}

\section{Animals}

Based on previous attempts at domesticating animals by selecting for tameness through a decreased fear of humans, a similar approach was attempted using the Red Junglefowl [129]. This experiment is unique in that the model used is a species that already has a history of domestication on which comparative studies are based, as seen in the former chapters. In an outbred population of Red Junglefowl, individuals 12 weeks of age were tested and scored in a fear of human test and divided in groups of high or low fearful animals based on those scores. This division in the parental population (Po) was the basis for the different selection lines, one used to generate a highly fearful line of Red Junglefowl and one used to breed a low fearful line of Red Junglefowl. Population sizes were kept at around 40 birds per selection line for the high and low fearful RJF from Po up until the fourth selected generation (S4), after which the total amount of animals were decreased to approximately 50 individuals for both selection lines together. Each subsequent generation was tested in the same standardized fear of human test by the same test person. The test, described in full by Agnvall et al [129], in short involves placing an individual Red Junglefowl in an enclosed rectangular arena divided into three zones. The test lasts three minutes, during which the observer takes notes of performed behaviors. For the first minute, the observer stands at one end of the arena, for the second minute they stand in the middle of the arena, and for the final minute they stand in the third zone. The test ends with the observer trying to touch the test subject and the fearful responses are recorded and evaluated to generate a total score for each bird. Only the most or least fearful birds within the high or low selection lines were used to breed new generations, and all breeding pairs were always from within the same generation with consideration to family structures. By the fifth generation of divergent selection ( 55$)$, the two selection lines of Red Junglefowl differed on a number of points, low fearful animals were larger in size, laid larger eggs which produced larger offspring, and had a higher frequency of aggressive behaviors during a social dominance test [130]. Also, the basal metabolic rate and feeding efficiency increased in low fearful birds, as did plasma serotonin levels in low fearful males [131].

\section{Transcriptome}

The results in papers I, III and IV are based on gene expression measurements performed through slightly different microarray techniques. For Paper I the GeneChip Chicken Genome Array from Affymetrix Inc. was used, it can analyze approximately 33000 unique transcripts using single color detection of fragmented cRNA hybridizing to the array. For Paper III the custom designed NimbleGen 12x135k oligonucleotide microarray (Roche) were used, and for Paper IV the SurePrint G3 Custom 8x6oK microarrays (Agilent). The NimbleGen array detect almost 33000 Ensembl, RefSeq 
and EST sequences from the chicken genome, whereas the Agilent detects slightly fewer because of the removal of EST probes. Both the latter arrays detect fluorescently labeled cDNA (Roche) or cRNA (Agilent) that hybridize oligonucleotide probes of known transcripts. Fluorescence data from the arrays is preprocessed by correcting for background signals and quantile normalized to yield measures of relative expression. Arrays where hybridization had not been successful were removed before all arrays were all normalized for the different experiments. For a minority of genes where different probes yielded contradictory results, the genes were removed from the analysis. Verification of microarray results was done through quantitative real time polymerase chain reaction (qPCR), normalized against housekeeping genes resulting in relative expression values.

\section{DNA Methylation}

In both Papers I and V, methylated DNA immunoprecipitation (MeDIP) was used to enrich methylated DNA. Genomic DNA is fragmented via sonication using ultrasound and fragments are captured and purified through the use of 5-methylcytosine specific antibodies. In Paper I, the methylated DNA fragments were quantified using a custom made tiling array. The tiling array, just like the microarray for transcription, is filled with 50-75bp long oligonucleotide probes designed to cover just over 3600 promoter regions in the chicken genome. Promoters for this experiment were defined as the region $7.25 \mathrm{~kb}$ upstream and $3.25 \mathrm{~kb}$ downstream of transcription start sites, and the oligonucleotides were evenly spaced out in the promoter region. For Paper V, the enriched MeDIP samples were analyzed through next generation sequencing and aligned to the Galgal4 chicken genome assembly. For both methods the amount of either probes or sequences gives a relative estimate of the amount of methylation, as they were captured by the antibodies.

Among the limitations of microarray studies is the need of a sequenced genome providing a priori knowledge of sequences and annotations. In 2004, the chicken was the first avian and domesticated species to have its genome sequenced, thereby providing a sound foundation for genomic analyses [132]. In a comparative study, sequencing reads and microarray hybridization intensity values correlate well with each other, and the few instances where probes detect transcripts not found by sequencing techniques might be due to cross-hybridization [133]. This crosshybridization is a major concern, complicating analysis of repetitive sequences and spliced transcripts, and could affect regions such as promoters in CpG-islands. The fact that different array formats have been used for the different experiments could introduce miniscule variation in terms of reproducibility [134], however the studies in this thesis do not compare quantified expression values and that should not affect the general conclusions. Sequencing platforms such as the one used for Paper V eliminate many of these problems. 


\section{Summary of papers}

Paper I: Transgenerational inheritance of gene expression and methylation patterns

\section{Background and aim}

Domestication of chickens has caused large phenotypic differences between the wild Red Junglefowl (RJF) and the domestic breeds. Among these changes are behavioral variation between wild and domestic chicken such as the White Leghorn (WL), and altered transgenerational inheritance patterns of environmentally acquired changes. RJF and WL are both affected by stimuli such as stress, but transmission of the effects from parent to offspring differ. In this paper, the hypothalamic transcriptome and promoter methylome were mapped in pairs of WL and RJF that also showed withinbreed variation for fearfulness. Offspring were generated from all pairs to also map the transgenerational effects of variation in fearfulness.

\section{Results and Conclusion}

Offspring from the different pairs displayed phenotypic variation reflecting their parents, indicating an inheritance of the phenotypes. Gene expression microarray and DNA methylation tiling array results showed inheritance of gene expression and epigenetic patterns in a breed specific manner, and also within breed reflecting variation in fearfulness. DNA methylation patterns were stable in the WL but disrupted in RJF. Interestingly, WL also showed patterns of hypermethylation in a majority of promoters differentially methylated between breeds. These results suggest that WL and RJF use different epigenetic pathways to transgenerationally transmit phenotypic traits, with DNA methylations having a more prominent role in the domestic WL, which could alter or improve the capability to transfer environmental information. 
Paper II: Changes in brain and organ size during selection against fear of humans

Background and aim

A common trait in most domestic animals is the proportional change in some organ sizes to total size. This could be an effect of selection against fear of humans, a trait vital for the domestication of a population. With many reports of changes or atrophy in tissues such as the brain or adrenals in domesticated animals, the aim of this paper was to compare organ size in RJF selected for either high or low fear of humans, as a first step towards domestication. These two groups already show behavioral and size differences after only five generations of selection.

\section{Results and Conclusion}

Brain and vital organs were weighed in parental (Po) and the fifth selected generation (S5) RJF. The relative brain weight decreased with tameness in $\mathrm{S}_{5} \mathrm{RJF}$, and several parts of the brain showed significant weight differences between $\mathrm{S}_{5}$ selection lines. The cerebral hemisphere was significantly smaller in low fear RJF, as was the heart, spleen and testis. The cerebellum was larger in the low fear RJF, and was the only tissue to change in this direction in low fear RJF. These findings are similar to those reported in other domesticated animals, and suggest that the early domestication process and selection against fear of humans have a significant impact on morphology and organ sizes in the Red Junglefowl. 
Paper III: Gene expression difference in hypothalamus in high and low fearful Red Junglefowl

\section{Background and aim}

Based on the large effects on behavior, morphology and fear of humans after only five generations of selection, we sought to study the transcriptional differences between high and low fearful RJF. Similar to the experimental setup in Paper I, the hypothalamus was selected due to its involvement in the stress response and its regulation of behavior. We used cDNA microarray analysis of the brain transcriptome, to determine the magnitude of change selection has had, and to examine what genes or pathways were affected.

\section{Results and Conclusion}

Analysis of the results showed that almost 350 genes were significantly differently expressed (DE) between high and low fearful RJF. Adjusting for multiple testing left 21 genes significantly DE, and annotations for some genes among these were linked to reproduction and the immune system. Gene ontology (GO) enrichment analysis of DE genes resulted in terms involved in mitochondrial activity and membrane parts. Expression differences in $\mathrm{S}_{5} \mathrm{RJF}$ are not seen in the parental generations, suggesting that selection for behavioral traits can cause stable expression changes in only a few generations. Whilst no immediate effects on the stress response related genes could be detected, the differences found in metabolic, immune, and reproduction related genes suggest that the change in fearfulness has changed the stress-related response in the selection lines. 
Paper IV: Gene expression difference in the cerebral hemisphere in high and low fearful Red Junglefowl

\section{Background and aim}

In this paper we continued examining changes in brain transcriptome caused by domestication. Based on previous studies of comparisons between domestic mammals and their wild counterparts, we focused on cerebral hemisphere tissue, a part of the brain involved in regulating social behaviors. As social interactions changed between high and low fearful RJF, gene expression differences in this tissue could shed light on some of the behavioral differences between selection lines. Moreover, with gene expression differences quantified in the hypothalamus of the $\mathrm{S}_{5}$ populations, the comparative analysis of changes and tissue-specificity can aid in determining different pathways important for early domestication.

Results and conclusion

Microarray analysis found 22 significantly differentially expressed genes between high and low fearful RJF in the fifth selected generation. Among genes affected in the low fearful group, several play a role in neuroendocrine function, such as RFT1, TOR3A and SNAP23. Furthermore, GO analysis of differentially expressed genes indicated enrichment of genes related to the mitochondria or protein binding, and KEGG pathway analysis yielded terms related to behavioral processes. Comparisons of differentially expressed genes with hypothalamic differences indicate tissue-specific effects on the transcriptome, and comparisons with cerebral expression in domestic animals points to species-specific changes in the chicken transcriptome. 
Paper V: DNA methylation changes in the hypothalamus as a result of selection for tameness

\section{Background and aim}

Papers III and IV examined the effects of domestication on the transcriptome, but the underlying causes for the transcriptional regulation are still not mapped. In the experiment in Paper I, large differences in methylation levels were found when comparing wild and domestic chicken. Here, in paper V, DNA from the hypothalamus of S5 RJF was used for methylated DNA immunoprecipitation sequencing (MEDIPseq), in order to measure methylation differences generated by the selection process, and association with previously described expression changes. Based on the results from Paper I, we expected a shift towards more methylated regions in low fearful RJF, and some, but not total, overlap with gene expression differences between high and low fearful RJF. DNA methylation, along with other epigenetic markers, may affect plasticity in populations, and could enable faster population level to selection pressures such as the fear of humans.

Results and conclusion

Overall, selection lines for low and high fearful RJF only differed significantly for a few regions after five generations. Annotations and GO analysis of windows with significantly differential methylation showed an enrichment in terms related to synapse parts, catalytic activity, substrate-specific transporter activity, and the mitochondrion. The DNA methylation patterns do not directly explain the variation in transcription, but annotation and GO enrichment indicate overlapping functions with DE genes in the hypothalamus. DNA methylation changes could explain some of the behavioral and other phenotypic differences caused by the selection process, but additional studies are needed in order to determine the extent of epigenetic regulation in the genome. Overall, the differences in DNA methylation are small but specific, further indicating the involvement of epigenetic patterns in shaping domestication in chickens. 


\section{Discussion}

The differences between wild and domestic animals have been presented in the introduction of this thesis, and cannot be overstated. Domestication has, as part of the domestic phenotype, changed aspects such as reproduction, size, feather or coat color, and behavior, as well as left its mark on the genome of the domestic animal. In Paper I, seminal for the later studies in this thesis, both genetic and DNA methylation differences between the Red Junglefowl and White Leghorn were investigated from a behavioral and transgenerational context. Papers II through V examine the differences between two selection lines of Red Junglefowl, building on the information gained from Paper I. Selection for a single behavioral response, fear of humans, has shown to not only to alter the group mean of fearfulness in only a few generations, but to also correlate with a number of other phenotypic and physiological changes. Fear and stress responses differ greatly between wild and domestic chickens, as well as within populations as demonstrated in Paper I, where pairs of high and low fearful birds were selected from both WL and RJF. Leading up to the experiment in Paper I were previous studies [73, 91, 135] that indicated that stressful events transgenerationally change the phenotype in offspring, and also that susceptibility and inheritance patterns differ between WL and RJF. With this in mind, the study in Paper I was performed in order to answer the question of how and why the inheritance patterns differ. Whilst Paper I presented general differences between WL and RJF, the fundamental aim of Papers III-V was not to locate candidate genes, thus, genes and pathways are discussed as potential modulators of trait variation and not causal candidates.

\section{Hypothalamic gene expression}

Papers I and III, explored hypothalamic transcription because this tissue regulates circadian rhythms, hunger, and neuroendocrine control [136]. The hypothalamus has also been well studied in the chicken in relation to stress responses and transgenerational effects. In Paper I, we identified a number of differentially expressed genes and methylated promoter regions. A few genes were selected to verify the results, and although the data and study design does not allow us to associate expression and methylation changes with phenotypes, the methylation patterns in an intercross between Red Junglefowl and White Leghorn do imply differences depending on genotype. There were only small amounts of variation in expression and methylation within breeds, compared to the hundreds to thousands of differentially expressed genes between the breeds. Gene ontology analysis of genes both differentially expressed (DE) and differentially methylated (DM) in both parents and offspring were enriched for intracellular signaling related terms, reflecting the behavioral differences between breeds.

In Paper III, fewer behaviorally related genes were found than expected, but studies in dogs and wild canids also found conserved expression profiles between wild populations and similar changes in wild vs domesticated populations. Additionally, 
similar conclusions were reached when comparing hypothalamic expression in tame and non-selected foxes [44], with unclear behavioral or stress relevance [137]. Amongst the most significant changes in dog domestication were neuropeptides affecting the HPA-axis, while corticotropin-releasing factor expression, CRF, did not differ between tame or aggressive foxes [88]. In the sixth selected generation of RJF, no changes in HPA reactivity was detected when measuring plasma corticosterone, indicating that fear selection had not yet affected the stress response [131]. Trut and colleagues [125] suggested that hormonal changes correlate with the degree of domestication, and in our case the $5^{\text {th }}$ selected generation might be too early to expect changes. Analysis between hypothalamus gene expression in Paper I and III did not show any major overlap, which is surprising, but could be explained by the Red Junglefowl populations differing from each other, as the selection line used in Paper III is a cross from two different Red Junglefowl populations [129].

The GO analysis indicated an enrichment in general terms related to cellular components, such as cytoplasmic and intracellular parts, proton transporting ATP synthase complex, and MHC class Ib protein complex. The unclear connection to changes in fear might be related to the lack of effect on the stress response, instead the findings indicate a change in the immune system, energy management, and overall structural changes. There was a growth difference between high and low fearful RJF in generation S5, with low fearful RJF growing faster and larger than high fearful RJF, and this will most likely influence the energetic demands, which is also seen in the change in basal metabolic rate in the $6^{\text {th }}$ selected generation [131]. A few genes overlapped with selective sweeps, amongst them two on growth1, LLPH and HELB. The growth1 QTL is the largest on chromosome one and also implicated in affecting social behavior and emotional reactivity $[138,139]$. The behavioral differences are not large between the high and low fearful RJF, which may be because behavior is more robust than morphology and physiology [140]. A selection experiment for high or low body weight in chickens saw in 50 generations a nine-fold difference in body weight, along with correlated changes in several other traits [139]. Already after seven generations of selection, significant changes in body weight was measured [141]. Seeing how weight is correlated with many other traits, it is not impossible to imagine that the selection for fear of humans will affect weight as well in the selection line. All in all, the relatively few changes in the hypothalamic transcriptome is not surprising considering the absence of stress response changes and behavioral trait variation.

\section{The cerebral hemisphere}

In Paper IV, the cerebral hemisphere transcriptome was studied. This part of the brain is involved in social cognition, learning, and associated behaviors [142, 143], and has been well studied in other domestication events [38, 39, 44, 45]. The right part of the cerebral hemisphere was chosen based on ease of identification among samples as well as previous studies on lateralization of behaviour in this tissue in the chicken [144, 145]. It is important to point out, however, that while our study focuses on the cerebral 
hemisphere, the avian brain does not possess the mammalian-specific six-layered cerebral cortex structure [146, 147].

Overall, the number of differentially expressed genes in Paper IV were almost equal to that of those in Paper III, both pre- and post FDR correction. Only a few genes, SPAG4, RFT1 and ENSGALGoooooo16237, overlapped between tissues after FDR correction, with $R F T 1$ being linked to cell signaling and a prospective modulator affecting the selected breed differences [148]. The other annotated gene, SPAG4, fills a function in the sperm, but no immediate justification for its expression in the brain is known. Expression in the high fear Po generation vary greatly, but the variation was small in $\mathrm{S}_{5}$ high fear within all individuals. The transcript either has a function in the brain that is currently unknown but related to a diverging trait between the groups, or the expression is caused by an allele that is fixed by generation $\mathrm{S}_{5}$. Considering tissues were collected from the same individuals at the same time for both studies, this rules out some confounding factors such as animal age differences or tissue handling. The overlap of genes pre FDR were threefold higher than by chance, which might be explained partly by the two studies examining brain tissues, and that the post FDR genes regulate tissue-specific differences. This reflects findings in farm fox populations, where despite the large behavioral and phenotypic changes, only a small set of transcripts differ between wild and tame foxes [44]. Gene ontology terms were as broad as in Paper III and did overlap, but none of the more specific terms did, similarly to what would be expected [40]. Among the specific terms in the cerebral hemisphere were neural crest development and differentiation. The neural crest cells, discussed earlier, are an interesting target for future studies of developmental differences in wild and domesticated chickens, as well as in mammals. During telencephalon development, NCCs participate in the enlargement of the brain in vertebrate species $[149,150]$. The trophic influence exercised by the NCCs could be what generates the differences in the cerebral hemisphere that were reported in Paper II, along with changes in other domesticated birds $[151,152]$. The consequence of size changes in the cerebral hemisphere are unclear, but considering KEGG pathway analysis resulted in terms as long-term potentiation, neurotrophin signaling and axon guidance, and differentially expressed glutamate related genes such as SNAP23, the changes could alter not only learning but also fear responses, as suggested in the domestication of dogs $[143,153,154]$. The full effects will need to be examined further, especially regarding learning. The more stable environment that captivity offers might affect learning, as it has done in domesticated chicken $[65,73]$.

\section{Morphological differences}

Besides the overall size and growth differences reported for the selection lines, relative organ sizes had also been affected in generation $\mathrm{S}_{5}$. Except for the cerebral hemisphere discussed previously, total brain size, the cerebellum, heart, spleen and testicles all differed significantly between high and low fearful RJF. Except for the cerebellum, 
which grew in size in the low fear population, the other mentioned organs were smaller in size in low fear RJF than in high fear RJF.

Although counter-intuitive, as organ size changes do not correlate positively with the size differences of the two groups, this might reflect a change in allocation of resources. Feeding behaviors in these RJF has changed as a response to selection, which could reflect foraging differences between wild and domestic chicken $[11,15]$ or differences in coping with the environment $[155,156]$.

\section{DNA Methylation differences}

The focus in Papers I and V is DNA methylations as an epigenetic marker which alters gene expression and is faithfully inherited over generations. As demonstrated in Paper I, there is a clear epigenetic difference between wild Red Junglefowl and the domesticated White Leghorn, individual variation exists within breeds, and both these patterns are inherited across generations. The increase in methylation in WL could have been acquired during domestication, or it could be a later and breed-specific change. The fact that WL but not RJF had a significant overlap between parental and offspring methylation patterns could also be an effect of the domestication process and importance of DNA methylation regulation on expression. The missing association between hypermethylation and downregulation of gene expression is puzzling, as previous studies have reported such correlations [157]. This could be explained by variation within promoters affecting interactions with methyl-CpG binding proteins in a complex manner [158]. It could also be affected at a hierarchically higher level, by histone modifications maintained or altered via cross-talk with DNA methylation. Our data is only for promoter regions, but gene-body methylation patterns can also influence expression patterns and regulatory protein interactions [104, 105]. In muscle tissue, $\mathrm{Li}$, Wang [36] find low difference in promoter methylations between wild and domestic chickens, despite large expression differences. Just as in our study, the global gene expression change between breeds could not be explained by promoter DNA methylation. Our main aim, however, was to study transgenerational inheritance of existing differences between breeds. The promoter DNA methylation levels were increased in the domesticated White Leghorn, and the domestication process may have affected the capacity to alter and transmit DNA methylation patterns transgenerationally, a sort of epigenomic plasticity [159]. The increase in DNA methylation was not seen in low fearful Red Junglefowl when compared to high fearful Red Junglefowl. Despite the few differences between the selection lines, the specificity of them, along with the larger breed differences of WL and RJF, support the hypothesis that epigenetic mechanisms aid in the transmission of environmental stimuli, and that one of these pathways is through DNA methylation.

\section{Gene regulation and domestication}

The variation within breeds, for fearfulness both in Paper I and in the parental population used for selection in Papers II-V, are signs of plasticity for those 
phenotypes. It is not farfetched to propose that the epigenetic mechanisms involved in that plasticity could permit environmental exposure to adjust gene expression, and that the acquired changes could be transgenerationally inherited [160, 161]. How this genetic accommodation actually occurs still needs to be investigated further.

As discussed earlier, gene expression and epigenetic overlaps were small, but since the transcriptional analysis in Paper III and IV were immediate and time-point specific measurements, and DNA methylation patterns do not necessarily need to have a genomic impact at the point of measurement in adult animals but could play relevant roles during development and maturation, implies that even the smallest of changes could have large effects $[162,163]$. Solving whether DNA methylation has been affected by selection, or if individual DNA methylation differences in the parental population have affected the selection outcome is impossible without information about the Po methylome, and even with that information the correlated responses during selection complicates things further. As shown in Papers III and IV, the gene expression patterns change from generation Po to $\mathrm{S}_{5}$, with significant changes in $\mathrm{S}_{5}$ due to the selection. Variation within Po is stochastic, patterns we at the moment can only assume are the same for DNA methylation until further studies are performed. Seeing how the methylation differences between sexes in Paper V are larger than those between WL and RJF in Paper I, it opens up for the possibility of parental variation and subsequent sex-specific susceptibility [164]. The large methylation differences between males and females could cause parent-specific patterns, and explain some of the sex-specific effects in the selection lines [165]. Finally, CpG methylations are dependent on the genome, and SNP variation has the potential to both allow and deny DNA methylation at specific positions. A study of speciation in Darwin finches suggests that methylation patterns are not only inherited over a few generations, but transgenerationally over millennia and can be as important as genomic mutations [111]. Methylations are also suggested to have modified the genome, adding a new layer of complexity to epigenetic mechanisms, with epimutations moving to the stable realm of the genome [110]. With the rapid changes domestication has caused in the chicken and all other domesticated animals, DNA methylations that form quickly as a response to selection could slowly alter the genome and boost the swift phenotypic alterations.

\section{Factors affecting selection}

Variation in fear behavior correlate positively with genetic variation in the chicken [166] and that is the basis for successful selection on a trait like fear of humans, the results of which are presented in this thesis. One can argue that five generations of selection is too short to find any meaningful or significant changes related to the future outcome of the selection process, but the data generated show promising developments when taking into account the short selection time. The data from papers II, III, and IV include comparisons within generations for both $\mathrm{Po}_{\mathrm{O}}$ and $\mathrm{S}_{5}$, and while there are significant differences for certain organ sizes and the transcriptome in $\mathrm{S}_{5}$, no sign of differences could be found within generation Po. In zebrafish selected for bold or shy 
personality traits, correlated changes in morphology and locomotion occur within only four to seven generations [167]. Furthermore, chickens selected for varying social dominance gave rise to divergent breed differences in only five generations [74]. The fact that selection for a behavioral trait succeeds is undeniable, the more important question lies in determining whether traits are directly or indirectly associated with each other. Is there correlational selection for other traits, or pleiotropic effects of the genes, or physiological mechanisms?

One factor affecting variation and the outcomes of selection is the population size. Founder populations usually have a low effective population size, and in cases with domestic animals it is paradoxical that they still manage to adapt to environments designed by humans [168]. Despite reduced effective population sizes and genetic variation, there is still sufficient variation for selection, illustrated by the selective sweeps in chickens with regions implied in growth differences [60]. Genetic variability is randomly reduced as an effect of captivity, via inbreeding and genetic drift, but domestic lines have not been kept reproductively isolated from wild lineages throughout history, counteracting some of the deleterious effects [169, 170]. Inbreeding equals increased homozygosity, which might be harmful, whilst genetic drift fix certain genes in a small population. So in small populations, the offspring allelic variation might not represent the parental allelic variation. And drift may by chance increase or decrease the allelic frequencies, which complicates things when trying to differentiate between effects of selection or drift [171]. In the silver fox populations, genetic diversity remains despite many generations of selective and separated breeding, and some regions diverge and may be targets for selection [172]. Long term selection on complex traits is the result of involvement of potentially hundreds of genes, and selection even in small populations will affect a large number of these, such as the case with growth in chickens [139].

Concerning the fear of humans trait, there is a symmetrical response during selection, while variability within selection lines occur, which suggests a polygenic means of inheritance and intermediate gene frequencies in the parental population. Genes affecting diverging traits in the selection lines might therefore be missing from the Paper III and IV datasets, as sample sizes and power were too small to find small effects. This occurs also in larger datasets, demonstrating the complexity of the genetic architecture of behavior [173]. The rapid phenotypic response in the selected RJF used in the studies of this thesis are probably due to existing variation, and such selection will not reduce variation as much as selection for a new mutation would. Further, polygenic traits will more likely only slightly change in frequency instead of going to fixation. Such selection will also be accompanied by strong linkage disequilibrium [174], which may cause morphological changes that do not appear to have a direct phenotypic correlation with the behavioral traits under selection [167].

The outcome of the selection experiment in Papers II through V are based on the differences of two single populations, which means only one replicate per selection 
line. As mentioned earlier, the outcome of any selection experiment is influenced by uncontrollable factors such as drift and the genetic structure and variation in a population [171]. Ideally, for a study such as this at least two more separate populations for each selection criteria would be necessary in order to draw conclusions based on more than just selection event, but even then conclusions cannot be drawn regarding the genetic correlation to traits. The selection response to fear of humans can most likely be repeated considering the bidirectional pattern of fear responses, but the underlying genetic architecture and correlated responses could be random.

\section{The effects of tameness}

In papers II through $\mathrm{V}$ we studied different aspects of the brain in the selection experiment. Taken together, the transcriptomic and epigenetic analyses provided genes and pathways that build a more coherent picture. The GO analysis outcome of both hypothalamus and cerebral hemisphere resulted in the same type of broad terms for cellular components, namely terms related to membranes and the mitochondria. The significant sets of genes from these studies were also enriched for protein and transcription factor binding, as well as response to stimulus. The mitochondria is the powerhouse of the cell, and alterations in activity have been proposed to affect behavioral disorders $[175,176]$. Also related are the metabolic and growth changes between the selection lines, but other tissues need to be examined in order to infer the causal genes for the size differences. The cerebral hemisphere is also a target for change in behaviorally relevant pathways and genes. Seeing how behaviors related to social interactions are among the few that differ between the selection lines, the findings suggest that the cerebral hemisphere needs more attention in comparative studies between wild and domestic breeds of chicken in order to pinpoint candidate genes for social behaviors. A few genes are highlighted as being of great interest in Paper IV, but seeing how poor the overlap between DE genes in hypothalamus was, the larger genomic changes from the long domestication process might have fixed other genes in the cerebral hemisphere causing the social behavior difference. The few DM genes in the hypothalamus were not DE, but their annotated functions indicate their potential role in similar pathways as DE genes, namely signaling, metabolism, reproduction and immunity, the last implicating silencing of foreign elements. Among these genes are USP3O, CAPN5, NALC and DDX25. The RJF used for these studies were sampled during the same conditions, meaning the expression patterns equals baseline behavior, and expression in the selection lines could differ from each other during stressful conditions. Only DNA methylations are analyzed in this thesis, but other epigenetic mechanisms like small or long non-coding RNAs, histone modifications, or even other DNA modifications such as 5-hydroxymethylcytosine could regulate transcription, as could existing genomic variation in the populations. 


\section{Conclusions}

To summarize, there are large significant expression differences between wild Red Junglefowl and the domestic White Leghorn, differences that are correlated with DNA methylations to only a small degree. Transgenerational inheritance of epigenetic markers also vary between the breeds. These differences are an effect of thousands of years of selection.

In a domestication experiment that has progressed for only five generations, a Red Junglefowl population have been separated into two distinct population displaying either high or low fear of humans. This divergent selection has caused phenotypic variation between the two groups that correlate with the selection trait differences. Small but significant transcription differences have appeared as a result of selection, and these differences are affecting parts of the brain in both tissue-specific and treatment-specific manners. These changes are accompanied by changes in DNA methylation between selection lines. The overall results support the hypothesis that selection for tameness is a key component in the early domestication process, and that it is aided by epigenetic factors. 


\section{Acknowledgements}

There are many people who have influenced me over the years, too many to mention within these pages.

I would like to thank:

My supervisor Per Jensen for this opportunity, and for all the guidance throughout the way. Few people are as inspiring, and without your advice and trust in me this journey would have felt far longer and more difficult to accomplish.

Bea, my thesis buddy. Without your groundwork in the selection experiment, this thesis would not have existed, and without you these last few months would have been immensely more tedious and so lonely.

Martin J, for all the help with statistics and R, and for indulging in discussions from serious matters regarding all aspects of science to other serious matters, like unicorns.

My partner in crime during the long spring semesters, Maria. The yang to my yin, the bad cop to my good cop (or was it the other way around?). Teaching would have been dull without you.

The AVIAN technicians you can always count on, Petros and Lejla. Whether lab work, animal care or something really obscure, you were always there providing help and your expertise.

My former colleagues Magnus, Milton and Markus. You taught me things I would otherwise have needed to learn the hard way. Research requires certain personality traits and ways of thinking, and you made sure I knew that going in.

Robin for reading and providing helpful comments on the thesis. Words not be good if you read not for me.

Amir, the go-to guy for honest reviews of series and movies, and critical judgement of $p$-values. You quickly became a close friend of mine, and I cherish all the interesting conversations we always manage to get into.

Past and present colleagues at the Biology department and for everyone turning up for the virtually mandatory fika breaks. And everyone attending Friday beer, the waterhole at the end of each week, where no discussion topic is ever too strange.

Patricio, my dear friend and anchor to reality. We know that one is the loneliest number, and two can be as bad as one. Yet all the after works and evenings with wine and whine lightened the mood during these last few years. 
Malin. You met me when I was struggling the most with my research and motivation, and now get to see the end result with this finished thesis. Your endless support and cheering for me, especially during these last months, has been invaluable and I hope to one day return the favor.

Végül szeretném megköszönni szüleimnek, Ágnesnek és Johannak. Ti azóta támogattátok az egyetemi kutatásomat, mióta elkötöztem, hogy egyetemista legyek. Toltatok a siker felé, és ezért soha nem lehetek elég hálás Nektek. Bárhová is visz az utam innen, tudom, hogy Ti ott lesztek nekem, ahogy mindig is ott voltatok. 


\section{References}

1. Price, E.O., Behavioral aspects of animal domestication. Quarterly Review of Biology, 1984. 59(1): p. 1-32.

2. Jensen, P. and D. Wright, Behavioral genetics and animal domestication. Genetics and the Behavior of Domestic Animals, 2nd edn. Academic Press (Elsevier), San Diego, California, 2014: p. 41-8o.

3. Zeder, M.A., Domestication and early agriculture in the Mediterranean Basin: Origins, diffusion, and impact. Proceedings of the National Academy of Sciences of the United States of America, 2008. 105(33): p. 11597-11604.

4. Frantz, L.A., et al., Evidence of long-term gene flow and selection during domestication from analyses of Eurasian wild and domestic pig genomes. Nat Genet, 2015. 47(10): p. 1141-1148.

5. Thalmann, O., et al., Complete Mitochondrial Genomes of Ancient Canids Suggest a European Origin of Domestic Dogs. Science, 2013. 342(6160): p. 871-874.

6. Frantz, L.A.F., et al., Genomic and archaeological evidence suggest a dual origin of domestic dogs. Science, 2016. 352(6290): p. 1228-1231.

7. Darwin, C., On the origin of species by means of natural selection, or, The preservation of favoured races in the struggle for life. Vol. -1859. 1859, London :: John Murray.

8. Clutton-Brock, J., The process of domestication. Mammal Review, 1992. 22(2): p. 79-85.

9. Trut, L.N., Early canid domestication: The farm-fox experiment. American Scientist, 1999. 87(2): p. 160-169.

10. Belyaev, D.K., I.Z. Plyusnina, and L.N. Trut, Domestication in the Silver fox (VULPES-FULVUS DESM) - Changes in physiological boundaries of the sensitive period of primary socialization. Applied Animal Behaviour Science, 1985. 13(4): p. 359-370.

11. Schutz, K., et al., QTL analysis of a red junglefowl $x$ white leghorn intercross reveals trade-off in resource allocation between behavior and production traits. Behavior Genetics, 2002. 32(6): p. 423-433.

12. Richter, C.P., Domestication of the Norway rat and its implication for the study of genetics in man. Am J Hum Genet, 1952. 4(4): p. 273-85.

13. Desforges, M.F. and D.G.M. Wood-Gush, A behavioural comparison of domestic and mallard ducks. Habituation and flight reactions. Animal Behaviour, 1975. 23, Part 3: p. 692-697.

14. Craig, J., Domestic animal behavior; causes and implications for animal and management. 1981.

15. Schütz, K.E., B. Forkman, and P. Jensen, Domestication effects on foraging strategy, social behaviour and different fear responses: a comparison between the red junglefowl (Gallus gallus) and a modern layer strain. Applied Animal Behaviour Science, 2001. 74(1): p. 1-14.

16. Güttinger, H.R., Consequences of Domestication on the Song Structures in the Canary. Behaviour, 1985. 94(3/4): p. 254-278.

17. Sánchez-Villagra, M.R., M. Geiger, and R.A. Schneider, The taming of the neural crest: a developmental perspective on the origins of morphological covariation in domesticated mammals. Royal Society Open Science, 2016. 3(6). 
18. Pigliucci, M., Phenotypic plasticity: beyond nature and nurture. 2001: JHU Press.

19. Morgan, K.N. and C.T. Tromborg, Sources of stress in captivity. Applied Animal Behaviour Science, 2007. 102(3-4): p. 262-302.

20. Künzl, C., et al., Is a wild mammal kept and reared in captivity still a wild animal? Hormones and Behavior, 2003. 43(1): p. 187-196.

21. Kretchmer, K. and M. Fox, Effects of domestication on animal behaviour. Veterinary Record, 1975. 96(5): p. 102-108.

22. Belyaev, D.K., Destabilizing selection as a factor in domestication. Journal of Heredity, 1979. 70(5): p. 301-308.

23. Trut, L., I. Oskina, and A. Kharlamova, Animal evolution during domestication: the domesticated fox as a model. Bioessays, 2009. 31(3): p. 349-60.

24. Malmkvist, J. and S.W. Hansen, The Welfare of Farmed Mink (Mustela Vison) in Relation to Behavioural Selection: A Review. Animal Welfare, 2001. 10(1): p. 41-52.

25. $\quad$ Albert, F.W., et al., Phenotypic differences in behavior, physiology and neurochemistry between rats selected for tameness and for defensive aggression towards humans. Horm Behav, 2008. 53(3): p. 413-21.

26. Hale, E., Domestication and the evolution of behaviour. The Behaviour of Domestic Animals, 2nd Edition (Ed. by ESE Hafez), 1969: p. 22-42.

27. Price, E.O. and J. King, Domestication and adaptation. Adaptation of Domestic Animals (Ed. by ESE Hafez), 1968: p. 34-45.

28. Savolainen, P., et al., Genetic evidence for an East Asian origin of domestic dogs. Science, 2002. 298(5598): p. 1610-3.

29. Eriksson, J., et al., Identification of the Yellow skin gene reveals a hybrid origin of the domestic chicken. PLoS Genet, 2008. 4(2).

30. Vilà, C., J. Seddon, and H. Ellegren, Genes of domestic mammals augmented by backcrossing with wild ancestors. Trends in Genetics, 2005. 21(4): p. 214218.

31. Muir, W.M., et al., Genome-wide assessment of worldwide chicken SNP genetic diversity indicates significant absence of rare alleles in commercial breeds. Proceedings of the National Academy of Sciences, 2008. 105(45): p. $17312-17317$.

32. Andersson, L. and M. Georges, Domestic-animal genomics: deciphering the genetics of complex traits. Nat Rev Genet, 2004. 5(3): p. 202-212.

33. Wilkins, A.S., R.W. Wrangham, and W.T. Fitch, The "Domestication Syndrome" in Mammals: A Unified Explanation Based on Neural Crest Cell Behavior and Genetics. Genetics, 2014. 197(3): p. 795-808.

34. Le Pape, E., et al., Microarray analysis sheds light on the dedifferentiating role of agouti signal protein in murine melanocytes via the Mc1r. Proceedings of the National Academy of Sciences, 2009. 106(6): p. 1802-1807.

35. Tymchuk, W., D. Sakhrani, and R. Devlin, Domestication causes large-scale effects on gene expression in rainbow trout: Analysis of muscle, liver and brain transcriptomes. General and Comparative Endocrinology, 2009. 164(2-3): p. 175-183.

36. Li, Q., et al., Gastrocnemius transcriptome analysis reveals domestication induced gene expression changes between wild and domestic chickens. Genomics, 2012. 100(5): p. 314-319. 
37. Chen, L., et al., Transcriptome analysis of adiposity in domestic ducks by transcriptomic comparison with their wild counterparts. Animal Genetics, 2015. 46(3): p. 299-307.

38. Albert, F.W., et al., A comparison of brain gene expression levels in domesticated and wild animals. PLoS Genet, 2012. 8(9): p. e1002962.

39. Li, Y., et al., Artificial selection on brain-expressed genes during the domestication of dog. Mol Biol Evol, 2013. 30(8): p. 1867-76.

40. Roy, M., et al., Analysis of the canine brain transcriptome with an emphasis on the hypothalamus and cerebral cortex. Mamm Genome, 2013. 24(11-12): p. 484-99.

41. Saetre, P., et al., From wild wolf to domestic dog: gene expression changes in the brain. Molecular Brain Research, 2004. 126(2): p. 198-206.

42. Fallahsharoudi, A., et al., Domestication Effects on Stress Induced Steroid Secretion and Adrenal Gene Expression in Chickens. Scientific Reports, 2015. 5: p. 10.

43. Albert, F.W., et al., Genetic architecture of tameness in a rat model of animal domestication. Genetics, 2009. 182(2): p. 541-54.

44. Lindberg, J., et al., Selection for tameness has changed brain gene expression in silver foxes. Current Biology, 2005. 15(22): p. R915-R916.

45. Kukekova, A.V., et al., Sequence comparison of prefrontal cortical brain transcriptome from a tame and an aggressive silver fox (Vulpes vulpes). BMC Genomics, 2011. 12: p. 482.

46. Nicol, C.J., The Behavioural Biology of Chickens. 2015: CABI.

47. Pheasantry, C. and H. Pradesh, An assessment of important physical traits shown by some captive red junglefowl in India. Current science, 2004. 87(11): p. 1498.

48. West, B. and B.X. Zhou, Did Chickens go North - New Evidence for Domestication. Journal of Archaeological Science, 1988. 15(5): p. 515-533.

49. Niu, D., et al., The Origin and Genetic Diversity of Chinese Native Chicken Breeds. Biochemical Genetics, 2002. 40(5): p. 163-174.

50. Dawkins, M.S., Time budgets in red junglefowl as a baseline for the assessment of welfare in domestic fowl. Applied Animal Behaviour Science, 1989. 24(1): p. 77-80.

51. Collias, N.E. and E.C. Collias, $A$ field study of the red jungle fowl in northcentral India. The Condor, 1967. 69(4): p. 360-386.

52. Savory, C., D. Wood-Gush, and I. Duncan, Feeding behaviour in a population of domestic fowls in the wild. Applied Animal Ethology, 1978. 4(1): p. 13-27.

53. Eda, M., et al., Reevaluation of early Holocene chicken domestication in northern China. Journal of Archaeological Science, 2016. 67: p. 25-31.

54. Peters, J., et al., Holocene cultural history of Red jungle fowl (Gallus gallus) and its domestic descendant in East Asia. Quaternary Science Reviews, 2016. 142: p. 102-119.

55. Liu, Y.-P., et al., Multiple maternal origins of chickens: Out of the Asian jungles. Molecular Phylogenetics and Evolution, 2006. 38(1): p. 12-19.

56. Miao, Y.W., et al., Chicken domestication: an updated perspective based on mitochondrial genomes. Heredity, 2013. 110(3): p. 277-282.

57. Wood-Gush, D.G.M., A History of the Domestic Chicken from Antiquity to the 19th Century. Poultry Science, 1959. 38(2): p. 321-326.

58. Zeuner, F.E., A History of Domesticated Animals. Hutchinson, London, 1963. 84s. Oryx, 1963. 7(2-3): p. 132-132. 
59. Girdland Flink, L., et al., Establishing the validity of domestication genes using DNA from ancient chickens. Proceedings of the National Academy of Sciences, 2014. 111(17): p. 6184-6189.

6o. Rubin, C.J., et al., Whole-genome resequencing reveals loci under selection during chicken domestication. Nature, 2010. 464(7288): p. 587-91.

61. Karlsson, A.-C., et al., A domestication related mutation in the thyroid stimulating hormone receptor gene (TSHR) modulates photoperiodic response and reproduction in chickens. General and Comparative Endocrinology, 2016. 228: p. 69-78.

62. Zuidhof, M.J., et al., Growth, efficiency, and yield of commercial broilers from 1957, 1978, and 2005. Poultry Science, 2014.

63. Vaisanen, J. and P. Jensen, Social versus exploration and foraging motivation in young red junglefowl (Gallus gallus) and White Leghorn layers. Applied Animal Behaviour Science, 2003. 84(2): p. 139-158.

64. Schutz, K.E., B. Forkman, and P. Jensen, Domestication effects on foraging strategy, social behaviour and different fear responses: a comparison between the red junglefowl (Gallus gallus) and a modern layer strain. Applied Animal Behaviour Science, 2001. 74(1): p. 1-14.

65. Lindqvist, C. and P. Jensen, Domestication and stress effects on contrafreeloading and spatial learning performance in red jungle fowl (Gallus gallus) and White Leghorn layers. Behavioural Processes, 2009. 81(1): p. 8o-84.

66. Väisänen, J., J. Håkansson, and P. Jensen, Social interactions in Red Junglefowl (Gallus gallus) and White Leghorn layers in stable groups and after re-grouping. British Poultry Science, 2005. 46(2): p. 156-168.

67. Kerje, S., et al., The twofold difference in adult size between the red junglefowl and White Leghorn chickens is largely explained by a limited number of QTLs. Animal Genetics, 2003. 34(4): p. 264-274.

68. Kerje, S., et al., The Dominant white, Dun and Smoky Color Variants in Chicken Are Associated With Insertion/Deletion Polymorphisms in the PMEL17 Gene. Genetics, 2004. 168(3): p. 1507-1518.

69. Keeling, L., et al., Chicken genomics: Feather-pecking and victim pigmentation. Nature, 2004. 431(7009): p. 645-646.

70. Nätt, D., et al., Plumage Color and Feather Pecking-Behavioral Differences Associated with PMEL17 Genotypes in Chicken (Gallus gallus). Behavior Genetics, 2007. 37(2): p. 399-407.

71. Schutz, K.E., et al., Major growth QTLs in fowl are related to fearful behavior: possible genetic links between fear responses and production traits in a red junglefowl $x$ White Leghorn intercross. Behavior Genetics, 2004. 34(1): p. 121-130.

72. Campler, M., M. Jöngren, and P. Jensen, Fearfulness in red junglefowl and domesticated White Leghorn chickens. Behavioural Processes, 2009. 81(1): p. 39-43.

73. Lindqvist, C., et al., Transmission of stress-induced learning impairment and associated brain gene expression from parents to offspring in chickens. PLoS One, 2007. 2(4): p. e364.

74. Craig, J.V., L.L. Ortman, and A.M. Guhl, Genetic selection for social dominance ability in chickens. Animal Behaviour, 1965. 13(1): p. 114-131.

75. Jöngren, M., et al., Brain gene expression in relation to fearfulness in female red junglefowl (Gallus gallus). Genes Brain Behav, 2010. 9(7): p. 751-8. 
76. Boissy, A., Fear and Fearfulness in Animals. The Quarterly Review of Biology, 1995. 70(2): p. 165-191.

77. Koolhaas, J.M., et al., Stress revisited: a critical evaluation of the stress concept. Neurosci Biobehav Rev, 2011. 35(5): p. 1291-301.

78. Love, O.P., P.O. McGowan, and M.J. Sheriff, Maternal adversity and ecological stressors in natural populations: the role of stress axis programming in individuals, with implications for populations and communities. Functional Ecology, 2013. 27(1): p. 81-92.

79. Romero, M.L. and L.K. Butler, Endocrinology of Stress. International Journal of Comparative Psychology, 2007. 2o(2).

80. Moberg, G.P. and J.A. Mench, The Biology of Animal Stress: Basic Principles and Implications for Animal Welfare. 2000: CABI Pub.

81. Solomon, G.F., S. Levine, and J.K. Kraft, Early Experience and Immunity. Nature, 1968. 220(5169): p. 821-822.

82. O'Mahony, S.M., et al., Early Life Stress Alters Behavior, Immunity, and Microbiota in Rats: Implications for Irritable Bowel Syndrome and Psychiatric Illnesses. Biological Psychiatry, 2009. 65(3): p. 263-267.

83. Shini, S., A. Shini, and G.R. Huff, Effects of chronic and repeated corticosterone administration in rearing chickens on physiology, the onset of lay and egg production of hens. Physiology \& Behavior, 2009. 98(1-2): p. 7377.

84. Satterlee, D.G., G.G. Cadd, and R.B. Jones, Developmental instability in japanese quail genetically selected for contrasting adrenocortical responsiveness. Poultry Science, 2000. 79(12): p. 1710-1714.

85. Jones, M.A., G. Mason, and N. Pillay, Early social experience influences the development of stereotypic behaviour in captive-born striped mice Rhabdomys. Applied Animal Behaviour Science, 2010. 123(1-2): p. 70-75.

86. Belyaev, D.K., Stress as a factor of genetic varation and the problem of destablizing selection. Folia Biologica, 1983. 29(2): p. 177-187.

87. Belyaev, D.K. and P.M. Borodin, The influence of stress on variation and its role in evolution. Biologisches Zentralblatt, 1982. 101(6): p. 705-714.

88. Gulevich, R.G., et al., Effect of selection for behavior on pituitary-adrenal axis and proopiomelanocortin gene expression in silver foxes (Vulpes vulpes). Physiology \& Behavior, 2004. 82(2-3): p. 513-518.

89. Clark, M.M. and B.G. Galef, Effects of rearing environment on adrenal weights, sexual development, and behavior in gerbils: An examination of Richter's domestication hypothesis. Journal of Comparative and Physiological Psychology, 1980. 94(5): p. 857-863.

90. Oskina, I.N., et al., Role of glucocorticoids in coat depigmentation in animals selected for behavior. Cytology and Genetics, 2010. 44(5): p. 286-293.

91. Goerlich, V.C., et al., Transgenerational effects of early experience on behavioral, hormonal and gene expression responses to acute stress in the precocial chicken. Horm Behav, 2012. 61(5): p. 711-8.

92. Ericsson, M., et al., Long-Term and Transgenerational Effects of Stress Experienced during Different Life Phases in Chickens (Gallus gallus). PLoS ONE, 2016. 11(4): p. e0153879.

93. Waddington, C.H., Organisers and genes. Organisers and Genes., 1940.

94. Waddington, C.H., The epigenotype. International journal of epidemiology, 2012. 41(1): p. 10-13.

95. Bird, A., Perceptions of epigenetics. Nature, 2007. 447(7143): p. 396-8. 
96. Holliday, R., Epigenetics: an overview. Developmental genetics, 1994. 15(6): p. $453-457$.

97. Wu, C. and J.R. Morris, Genes, genetics, and epigenetics: a correspondence. Science, 2001. 293(5532): p. 1103-5.

98. Deans, C. and K.A. Maggert, What Do You Mean, "Epigenetic"? Genetics, 2015. 199(4): p. 887-896.

99. Bird, A.P., CpG-rich islands and the function of DNA methylation. Nature, 1985. 321(6067): p. 209-213.

100. Gardiner-Garden, M. and M. Frommer, $C p G$ Islands in vertebrate genomes. Journal of Molecular Biology, 1987. 196(2): p. 261-282.

101. Gonzalgo, M.L. and P.A. Jones, Mutagenic and epigenetic effects of DNA methylation. Mutation Research/Reviews in Mutation Research, 1997. 386(2): p. 107-118.

102. Antequera, F., Structure, function and evolution of CpG island promoters. Cellular and Molecular Life Sciences CMLS, 2003. 6o(8): p. 1647-1658.

103. Comb, M. and H.M. Goodman, $C p G$ methylation inhibits proenkephalin gene expression and binding of the transcription factor AP-2. Nucleic Acids Research, 1990. 18(13): p. 3975-3982.

104. Lewis, J.D., et al., Purification, sequence, and cellular localization of a novel chromosomal protein that binds to Methylated DNA. Cell, 1992. 69(6): p. 905-914.

105. Hellman, A. and A. Chess, Gene Body-Specific Methylation on the Active $X$ Chromosome. Science, 2007. 315(5815): p. 1141-1143.

106. Weber, M., et al., Distribution, silencing potential and evolutionary impact of promoter DNA methylation in the human genome. Nat Genet, 2007. 39(4): p. 457-66.

107. Gruenbaum, Y., H. Cedar, and A. Razin, Substrate and sequence specificity of a eukaryotic DNA methylase. Nature, 1982. 295(5850): p. 620-622.

108. Morgan, H.D., et al., Epigenetic reprogramming in mammals. Hum Mol Genet, 2005. 14 Spec No 1: p. R47-58.

109. Skinner, M.K., et al., Transgenerational Epigenetic Programming of the Brain Transcriptome and Anxiety Behavior. PLoS One, 2008. 3(11).

110. Guerrero-Bosagna, C., et al., Epigenetic Transgenerational Actions of Vinclozolin on Promoter Regions of the Sperm Epigenome. PLoS ONE, 2010. 5(9): p. e1310o.

111. Skinner, M.K., et al., Epigenetics and the Evolution of Darwin's Finches. Genome Biology and Evolution, 2014. 6(8): p. 1972-1989.

112. Morgan, H.D., et al., Epigenetic inheritance at the agouti locus in the mouse. Nat Genet, 1999. 23(3): p. 314-318.

113. Dolinoy, D.C., et al., Variable histone modifications at the Avymetastable epiallele. Epigenetics, 2010. 5(7): p. 637-644.

114. Rakyan, V.K., et al., Metastable epialleles in mammals. Trends in Genetics, 2002. 18(7): p. 348-351.

115. Waterland, R.A. and R.L. Jirtle, Transposable Elements: Targets for Early Nutritional Effects on Epigenetic Gene Regulation. Molecular and Cellular Biology, 2003. 23(15): p. 5293-5300.

116. Weaver, I.C., et al., Epigenetic programming by maternal behavior. Nat Neurosci, 2004. 7(8): p. 847-54.

117. Nikolova, Y.S., et al., Beyond genotype: serotonin transporter epigenetic modification predicts human brain function. Nat Neurosci, 2014. 17(9): p. 1153-1155. 
118. Caspi, A., et al., Genetic Sensitivity to the Environment: The Case of the Serotonin Transporter Gene and Its Implications for Studying Complex Diseases and Traits. American Journal of Psychiatry, 2010. 167(5): p. 509527.

119. Ho, M.W. and P.T. Saunders, Beyond neo-Darwinism-an epigenetic approach to evolution. Journal of Theoretical Biology, 1979. 78(4): p. 573-591.

120. Jensen, P., Adding 'epi-' to behaviour genetics: implications for animal domestication. J Exp Biol, 2015. 218(Pt 1): p. 32-40.

121. Jablonka, E. and G. Raz, Transgenerational Epigenetic Inheritance: Prevalence, Mechanisms, and Implication for the Study of Heredity and Evolution. Quarterly Review of Biology, 2009. 84(2): p. 131-176.

122. Trerotola, M., et al., Epigenetic inheritance and the missing heritability. Human Genomics, 2015. 9: p. 12.

123. Lickliter, R. and J.W. Ness, Domestication and comparative psychology: Status and strategy. Journal of Comparative Psychology, 1990. 104(3): p. 211218.

124. Feeney, A., E. Nilsson, and M.K. Skinner, Epigenetics and transgenerational inheritance in domesticated farm animals. Journal of Animal Science and Biotechnology, 2014. 5(1): p. 1-7.

125. Trut, L.N., I.Z. Plyusnina, and I.N. Oskina, An Experiment on Fox Domestication and Debatable Issues of Evolution of the Dog. Russian Journal of Genetics, 2004. 40(6): p. 644-655.

126. Tsigos, C., et al., Receptors for Melanocortin Peptides in the HypothalamicPituitary-Adrenal Axis and Skin. Annals of the New York Academy of Sciences, 1995. 771(1): p. 352-363.

127. Murphy, B., et al., Melanocortin mediated inhibition of feeding behavior in rats. Neuropeptides, 1998. 32(6): p. 491-497.

128. Gulevich, R., et al., The non-agouti mutation in Norway rats (Rattus norvegicus) selected for behavior. Canadian Journal of Zoology-Revue Canadienne De Zoologie, 2013. 91(3): p. 111-117.

129. Agnvall, B., et al., Heritability and genetic correlations of fear-related behaviour in Red Junglefowl--possible implications for early domestication. PLoS One, 2012. 7(4): p. e35162.

130. Agnvall, B., et al., Red Junglefowl (Gallus gallus) selected for low fear of humans are larger, more dominant and produce larger offspring. Animal, 2014. 8(9): p. 1498-505.

131. Agnvall, B., et al., Is domestication driven by reduced fear of humans? Boldness, metabolism and serotonin levels in divergently selected red junglefowl (Gallus gallus). Biol Lett, 2015. 11(9).

132. Int Chicken Genome Sequencing, C., Sequence and comparative analysis of the chicken genome provide unique perspectives on vertebrate evolution (vol 432, pg 695, 2004). Nature, 2005. 433(7027): p. 777-777.

133. Git, A., et al., Systematic comparison of microarray profiling, real-time PCR, and next-generation sequencing technologies for measuring differential microRNA expression. Rna, 2010. 16(5): p. 991-1006.

134. Hurd, P.J. and C.J. Nelson, Advantages of next-generation sequencing versus the microarray in epigenetic research. Briefings in Functional Genomics, 2009.

135. Nätt, D., et al., Inheritance of acquired behaviour adaptations and brain gene expression in chickens. PLoS One, 2009. 4(7): p. e6405. 
136. Kuenzel, W.J. and A. Jurkevich, Molecular neuroendocrine events during stress in poultry. Poultry Science, 2010. 89(4): p. 832-840.

137. Lindberg, J., et al., Selection for tameness modulates the expression of heme related genes in silver foxes. Behavioral and Brain Functions, 2007. 3(1): p. 110.

138. Wiren, A. and P. Jensen, A Growth QTL on Chicken Chromosome 1 Affects Emotionality and Sociality. Behavior Genetics, 2011. 41(2): p. 303-311.

139. Johansson, A.M., et al., Genome-Wide Effects of Long-Term Divergent Selection. PLoS Genet, 2010. 6(11): p. e1001188.

140. Agnvall, B. and P. Jensen, Effects of divergent selection for fear of humans on behaviour in Red Junglefowl. In Press.

141. Dunnington, E. and P. Siegel, Long-term selection for 8-week body weight in chickens-direct and correlated responses. Theoretical and applied genetics, 1985. 71(2): p. 305-313.

142. Adolphs, R., The neurobiology of social cognition. Current Opinion in Neurobiology, 2001. 11(2): p. 231-239.

143. Cipolla-Neto, J., G. Horn, and B.J. McCabe, Hemispheric asymmetry and imprinting: The effect of sequential lesions to the hyperstriatum ventrale. Experimental Brain Research, 1982. 48(1): p. 22-27.

144. Daisley, J.N., et al., Lateralization of social cognition in the domestic chicken (Gallus gallus). Philosophical Transactions of the Royal Society of London B: Biological Sciences, 2009. 364(1519): p. 965-981.

145. Salva, O.R., et al., Lateralization of social learning in the domestic chick, Gallus gallus domesticus: learning to avoid. Animal Behaviour, 2009. 78(4): p. 847-856.

146. The Avian Brain Nomenclature, C., Avian brains and a new understanding of vertebrate brain evolution. Nature reviews. Neuroscience, 2005. 6(2): p. 151159.

147. Dugas-Ford, J., J.J. Rowell, and C.W. Ragsdale, Cell-type homologies and the origins of the neocortex. Proceedings of the National Academy of Sciences, 2012. 109(42): p. 16974-16979.

148. Patterson, M.C., Metabolic Mimics: The Disorders of N-Linked Glycosylation. Seminars in Pediatric Neurology, 2005. 12(3): p. 144-151.

149. Etchevers, H.C., et al., Anterior cephalic neural crest is required for forebrain viability. Development, 1999. 126(16): p. 3533-3543.

150. Etchevers, H.C., et al., The cephalic neural crest provides pericytes and smooth muscle cells to all blood vessels of the face and forebrain.

Development, 2001. 128(7): p. 1059-1068.

151. Ebinger, P. and R. Löhmer, Comparative quantitative investigations on brains of rock doves, domestic and urban pigeons (Columba 1. livia)1. Journal of Zoological Systematics and Evolutionary Research, 1984. 22(2): p. 136-145.

152. Ebinger, P. and M. Rohrs, Volumetric analysis of brain structures, especially of the visual system in wild and domestic turkeys (MELEAGRISGALLOPAVO). Journal of Brain Research-Journal Fur Hirnforschung, 1995. 36(2): p. 219-228.

153. Rioult-Pedotti, M.-S., D. Friedman, and J.P. Donoghue, Learning-Induced LTP in Neocortex. Science, 2000. 290(5491): p. 533-536.

154. Li, Y., et al., Domestication of the Dog from the Wolf Was Promoted by Enhanced Excitatory Synaptic Plasticity: A Hypothesis. Genome Biology and Evolution, 2014. 6(11): p. 3115-3121. 
155. Solberg, M.F., et al., Does domestication cause changes in growth reaction norms? A study of farmed, wild and hybrid Atlantic salmon families exposed to environmental stress. PLoS One, 2013. 8(1): p. e54469.

156. Tchernov, E. and L.K. Horwitz, Body size diminution under domestication: Unconscious selection in primeval domesticates. Journal of Anthropological Archaeology, 1991. 10(1): p. 54-75.

157. Li, Q., et al., Genome-wide mapping of DNA methylation in chicken. PLoS One, 2011. 6(5): p. e19428.

158. Lan, J., et al., DNA methyltransferases and methyl-binding proteins of mammals. Acta biochimica et biophysica Sinica, 2010. 42(4): p. 243-252.

159. Johnson, L.J. and P.J. Tricker, Epigenomic plasticity within populations: its evolutionary significance and potential. Heredity, 2010. 105(1): p. 113-121.

160. Duncan, E.J., P.D. Gluckman, and P.K. Dearden, Epigenetics, Plasticity, and Evolution: How do We Link Epigenetic Change to Phenotype? Journal of Experimental Zoology Part B-Molecular and Developmental Evolution, 2014. 322(4): p. 208-220.

161. Schlichting, C.D. and M.A. Wund, Phenotypic Plasticity and Epigenetic Marking: An Assessment of Evidence for Genetic Accommodation. Evolution, 2014. 68(3): p. 656-672.

162. Schneider, E., et al., Spatial, temporal and interindividual epigenetic variation of functionally important DNA methylation patterns. Nucleic Acids Research, 2010. 38(12): p. 3880-3890.

163. Siegmund, K.D., et al., DNA Methylation in the Human Cerebral Cortex Is Dynamically Regulated throughout the Life Span and Involves Differentiated Neurons. PLoS ONE, 2007. 2(9): p. e895.

164. Nätt, D., B. Agnvall, and P. Jensen, Large sex differences in chicken behavior and brain gene expression coincide with few differences in promoter DNAmethylation. PLoS One, 2014. 9(4): p. e96376.

165. Tuiskula-Haavisto, M. and J. Vilkki, Parent-of-origin specific QTL - a possibility towards understanding reciprocal effects in chicken and the origin of imprinting. Cytogenetic and Genome Research, 2007. 117(1-4): p. 305-312.

166. Håkansson, J., Behavioural aspects of conservation breeding Red junglefowl (Gallus gallus) as a case study. 2007: Institutionen för fysik, kemi och biologi.

167. Kern, E.M.A., et al., Correlated evolution of personality, morphology and performance. Animal Behaviour, 2016. 117: p. 79-86.

168. Stanley, C.E. and R.J. Kulathinal, Genomic signatures of domestication on neurogenetic genes in Drosophila melanogaster. BMC Evolutionary Biology, 2016. 16(1): p. 1-14.

169. Vila, C., J. Seddon, and H. Ellegren, Genes of domestic mammals augmented by backcrossing with wild ancestors. Trends in Genetics, 2005. 21(4): p. 214218.

170. Larson, G. and J. Burger, A population genetics view of animal domestication. Trends Genet, 2013. 29(4): p. 197-205.

171. Gromko, M.H., Unpredictability of Correlated Response to Selection: Pleiotropy and Sampling Interact. Evolution, 1995. 49(4): p. 685-693.

172. Johnson, J.L., et al., Genotyping-By-Sequencing (GBS) Detects Genetic Structure and Confirms Behavioral QTL in Tame and Aggressive Foxes (Vulpes vulpes). Plos One, 2015. 10(6): p. 22.

173. Heyne, H.O., et al., Genetic influences on brain gene expression in rats selected for tameness and aggression. Genetics, 2014. 198(3): p. 1277-90. 
174. Albert, F.W., et al., Targeted resequencing of a genomic region influencing tameness and aggression reveals multiple signals of positive selection. Heredity, 2011. 107(3): p. 205-214.

175. Gardner, A. and R.G. Boles, Beyond the serotonin hypothesis: Mitochondria, inflammation and neurodegeneration in major depression and affective spectrum disorders. Progress in Neuro-Psychopharmacology and Biological Psychiatry, 2011. 35(3): p. 730-743.

176. Anitha, A., et al., Brain region-specific altered expression and association of mitochondria-related genes in autism. Molecular Autism, 2012. 3(1): p. 12. 
